\title{
The acid-catalyzed hydrolysis of an $\alpha$-pinene-derived organic nitrate: kinetics, products, reaction mechanisms, and atmospheric impact
}

\author{
Joel D. Rindelaub, Carlos H. Borca, Matthew A. Hostetler, Jonathan H. Slade, Mark A. Lipton, \\ Lyudmila V. Slipchenko, and Paul B. Shepson \\ Department of Chemistry, Purdue University, West Lafayette, IN 47907, USA \\ Correspondence to: Joel D. Rindelaub (jrindela@purdue.edu) and Paul B. Shepson (pshepson@purdue.edu) \\ Received: 11 August 2016 - Published in Atmos. Chem. Phys. Discuss.: 12 August 2016 \\ Revised: 10 November 2016 - Accepted: 17 November 2016 - Published: 13 December 2016
}

\begin{abstract}
The production of atmospheric organic nitrates $\left(\mathrm{RONO}_{2}\right)$ has a large impact on air quality and climate due to their contribution to secondary organic aerosol and influence on tropospheric ozone concentrations. Since organic nitrates control the fate of gas phase $\mathrm{NO}_{x}\left(\mathrm{NO}+\mathrm{NO}_{2}\right)$, a byproduct of anthropogenic combustion processes, their atmospheric production and reactivity is of great interest. While the atmospheric reactivity of many relevant organic nitrates is still uncertain, one significant reactive pathway, condensed phase hydrolysis, has recently been identified as a potential sink for organic nitrate species. The partitioning of gas phase organic nitrates to aerosol particles and subsequent hydrolysis likely removes the oxidized nitrogen from further atmospheric processing, due to large organic nitrate uptake to aerosols and proposed hydrolysis lifetimes, which may impact long-range transport of $\mathrm{NO}_{x}$, a tropospheric ozone precursor. Despite the atmospheric importance, the hydrolysis rates and reaction mechanisms for atmospherically derived organic nitrates are almost completely unknown, including those derived from $\alpha$ pinene, a biogenic volatile organic compound (BVOC) that is one of the most significant precursors to biogenic secondary organic aerosol (BSOA). To better understand the chemistry that governs the fate of particle phase organic nitrates, the hydrolysis mechanism and rate constants were elucidated for several organic nitrates, including an $\alpha$-pinene-derived organic nitrate (APN). A positive trend in hydrolysis rate constants was observed with increasing solution acidity for all organic nitrates studied, with the tertiary APN lifetime ranging from $8.3 \mathrm{~min}$ at acidic $\mathrm{pH}(0.25)$ to $8.8 \mathrm{~h}$ at neutral $\mathrm{pH}$ (6.9). Since ambient fine aerosol $\mathrm{pH}$ values are observed to be acidic, the reported lifetimes, which are much shorter than
\end{abstract}

that of atmospheric fine aerosol, provide important insight into the fate of particle phase organic nitrates. Along with rate constant data, product identification confirms that a unimolecular specific acid-catalyzed mechanism is responsible for organic nitrate hydrolysis under acidic conditions. The free energies and enthalpies of the isobutyl nitrate hydrolysis intermediates and products were calculated using a hybrid density functional ( $\omega \mathrm{B} 97 \mathrm{X}-\mathrm{V})$ to support the proposed mechanisms. These findings provide valuable information regarding the organic nitrate hydrolysis mechanism and its contribution to the fate of atmospheric $\mathrm{NO}_{x}$, aerosol phase processing, and BSOA composition.

\section{Introduction}

The atmospheric oxidation of biogenic volatile organic compounds (BVOCs), which have annual emission rates ( $\sim 1100 \mathrm{Tg} \mathrm{yr}^{-1}$ total) roughly 1 order of magnitude larger than anthropogenic non-methane VOCs (Guenther et al., 1995), has a significant impact on air quality and climate. The production of secondary organic aerosol (SOA) from $\mathrm{BVOC}$ oxidation products influences the radiative balance of the planet by directly interacting with both solar and terrestrial radiation, as well as indirectly through their role as cloud condensation nuclei (e.g., Ramanathan et al., 2001). Overall, the production of SOA from BVOCs has a cooling effect on global climate, estimated to have a combined radiative forcing as large as $-1.5 \mathrm{~W} \mathrm{~m}^{-2}$ (Scott et al., 2014). Additionally, the inhalation of SOA has a significant impact on the hu- 


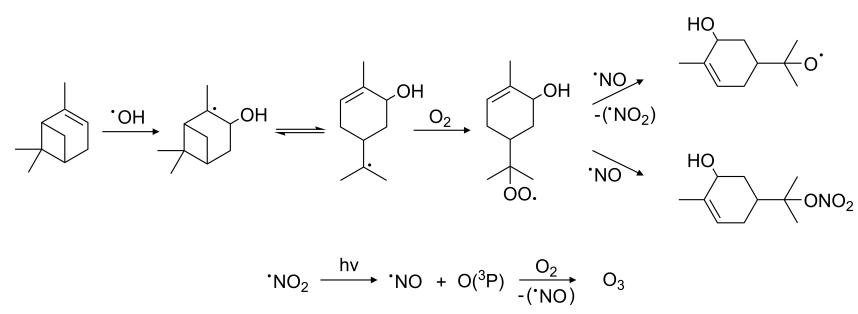

Figure 1. The formation of atmospheric organic nitrates and ozone from the gas phase oxidation of $\alpha$-pinene, initiated by the $\mathrm{OH}$ radical.

man respiratory system and atmospheric aerosol concentrations are positively correlated with lung cancer and mortality rates (Raaschou-Nielsen et al., 2013). Despite the importance of SOA, the chemical mechanisms that explain the composition of aerosol particles and their chemical processes are still highly uncertain.

The gas phase oxidation of BVOCs also governs tropospheric ozone concentrations by controlling its precursor, $\mathrm{NO}_{x}\left(\mathrm{NO}+\mathrm{NO}_{2}\right)$. In the atmosphere, the most common atmospheric oxidant, the $\mathrm{OH}$ radical, can either abstract a hydrogen from or add to a BVOC, if it contains an olefinic functionality (e.g., $\alpha$-pinene), to create a peroxy radical from the rapid addition of molecular oxygen to the organic radical (Fig. 1). In high $\mathrm{NO}_{x}$ environments, such as areas within atmospheric transport of combustion emissions, nitric oxide can either add to the peroxy radical to form an organic nitrate $\left(\mathrm{RONO}_{2}\right)$ or it can be oxidized to create an alkoxy radical and $\mathrm{NO}_{2}$, which can readily photolyze to produce ozone (Fig. 1). The ratio of $\mathrm{RONO}_{2}$ production to $\mathrm{NO}_{2}$ production is referred to as the organic nitrate branching ratio. Since ozone is a greenhouse gas (IPCC, 2007), damages plants and crops (Fiscus et al., 2005), and is a lung irritant (EPA, 2011), the formation and fate of organic nitrates have implications for both climate and environmental health.

With respect to SOA production, among the most important BVOC-derived organic nitrates are products of $\alpha$ pinene oxidation, due to their relatively low volatility and the high annual global emission rate of $\alpha$-pinene $\left(\sim 66 \mathrm{Tg} \mathrm{yr}^{-1}\right.$; Guenther et al., 2012). $\alpha$-Pinene-derived organic nitrates (APNs) can comprise a significant fraction of SOA mass (Xu et al., 2015; Rollins et al., 2010). At elevated relative humidity, when aerosol particles have increased liquid water content, organic nitrates can hydrolyze in the particle phase to eliminate the $\mathrm{RONO}_{2}$ functionality (Liu et al., 2012; Rindelaub et al., 2015; Boyd et al., 2015; Bean and Hildebrandt Ruiz, 2016), leaving the nitrate ion within the particle. However, the products, mechanisms, and kinetics of the APN hydrolysis reactions are still unknown, negatively impacting our understanding of aerosol phase chemistry and the fate of atmospheric $\mathrm{NO}_{x}$.

The conversion of the organic nitrate functionality to a nonvolatile, largely unreactive nitrate ion via a substitution or elimination mechanism would lead to an effective sink of atmospheric $\mathrm{NO}_{x}$ and reduce the potential for $\mathrm{NO}_{x} / \mathrm{O}_{3}$ transport. Recent results from Romer et al. (2016) indicate that the lifetime of atmospheric boundary layer $\mathrm{NO}_{x}$ could be as low as $\sim 2 \mathrm{~h}$, using an assumed short hydrolysis lifetime (Romer et al., 2016). The hydrolysis mechanism could also potentially impact SOA formation and cloud condensation nuclei activity. Thus, the hydrolysis of organic nitrates, and the associated uncertainty, has a significant impact on our understanding of how $\mathrm{BVOC}-\mathrm{NO}_{x}$ interactions affect climate, air quality, and health.

Despite much study of organic nitrate hydrolysis, the rates and mechanisms at low $\mathrm{pH}$, which is relevant to both ambient (e.g., Guo et al., 2015) and laboratory conditions (Rindelaub et al., 2016), are still very uncertain. While $S_{N} 2$ mechanisms are believed to be more prevalent at high $\mathrm{pH}$ (Baker and Easty, 1950; Boschan et al., 1955), recent studies suggest that unimolecular mechanisms are responsible for the fate of organic nitrates under aqueous acidic conditions due to the polar protic solvent system, water's weak nucleophilicity, and the relatively large observed hydrolysis rates for tertiary organic nitrates (Rindelaub et al., 2015). While the reaction is likely acid-catalyzed, the catalysis mechanism is uncertain since both specific and general catalyzed mechanisms have been proposed (Darer et al., 2011; Jacobs et al., 2014).

To better understand the organic nitrate hydrolysis mechanism and kinetics under acidic conditions and the corresponding impact on atmospheric processes, hydrolysis reactions were performed focusing on the fate of APNs. The hydrolysis rate constants, specific mechanism, and main product were determined for a laboratory-synthesized APN. The hydrolysis of simple alkyl nitrates, isopropyl nitrate (IPN) and isobutyl nitrate (IBN), were also studied to gain insight into the mechanisms of primary and secondary substituted species and to enable computational chemistry studies of the mechanism and energetics. The results from this study help improve our understanding of organic nitrate chemistry, the fate of atmospherically relevant organic nitrates relating to climate and health, and can help explain important mechanisms that impact aerosol phase chemistry.

\section{Experiment}

\subsection{Materials and methods}

Organic nitrate hydrolysis reactions were studied for isopropyl nitrate (Sigma Aldrich, >99\%), isobutyl nitrate (Sigma Aldrich, $>97 \%$ ), and a hydroxyl organic nitrate derived from $\alpha$-pinene by injecting $10 \mu \mathrm{L}$ of a given standard into a $100 \mathrm{~mL}$ buffered solution that was continuously mixed. The $\alpha$-pinene-derived nitrate, shown in Fig. 1, was synthesized based on Pinto et al. (2007). Briefly, $\alpha$-pinene oxide was added to a $1.0 \mathrm{M}$ solution of $\mathrm{Bi}\left(\mathrm{NO}_{3}\right)_{3} \cdot 5 \mathrm{H}_{2} \mathrm{O}$ in dichloromethane (DCM), and stirred for $1 \mathrm{~h}$ under $\mathrm{N}_{2}$ before 
Table 1. Stoichiometry of the calculated states.

\begin{tabular}{ll}
\hline State & Species included \\
\hline IBN & $\left(\mathrm{CH}_{3}\right)_{2} \mathrm{CHCH}_{2} \mathrm{ONO}_{2}+\mathrm{H}_{3} \mathrm{O}^{+}+\mathrm{H}_{2} \mathrm{O}$ \\
IBHN $^{+}$ & $\left(\mathrm{CH}_{3}\right)_{2} \mathrm{CHCH}_{2} \mathrm{ONO}_{2} \mathrm{H}^{+}+2 \mathrm{H}_{2} \mathrm{O}$ \\
$\mathrm{IB}^{+}$ & $\left(\mathrm{CH}_{3}\right)_{2} \mathrm{CHCH}_{2}^{+}+\mathrm{HNO}_{3}+2 \mathrm{H}_{2} \mathrm{O}$ \\
$\mathrm{TB}^{+}$ & $\left(\mathrm{CH}_{3}\right)_{2} \mathrm{C}^{+} \mathrm{CH}_{3}+\mathrm{HNO}_{3}+2 \mathrm{H}_{2} \mathrm{O}$ \\
2MP & $\left(\mathrm{CH}_{3}\right)_{2} \mathrm{C}=\mathrm{CH}_{2}+\mathrm{HNO}_{3}+\mathrm{H}_{3} \mathrm{O}^{+}+\mathrm{H}_{2} \mathrm{O}$ \\
IBA & $\left(\mathrm{CH}_{3}\right)_{2} \mathrm{CHCH} \mathrm{CH}_{2} \mathrm{OHNO} \mathrm{HNO}_{3}+\mathrm{H}_{3} \mathrm{O}^{+}$ \\
TBA & $\left(\mathrm{CH}_{3}\right)_{3} \mathrm{COH}+\mathrm{HNO}_{3}+\mathrm{H}_{3} \mathrm{O}^{+}$ \\
\hline
\end{tabular}

purification using flash chromatography with a $20 \%$ ethyl acetate in hexane solvent system. Product identification and purity were assessed using ${ }^{1} \mathrm{H}$ and ${ }^{13} \mathrm{C}$ nuclear magnetic resonance spectroscopy (NMR) (see Sect. S1 in the Supplement). Aliquots of $5 \mathrm{~mL}$ were taken at varying time points from the reaction mixture and extracted with $5 \mathrm{~mL}$ of tetrachloroethylene $\left(\mathrm{C}_{2} \mathrm{Cl}_{4}\right)$ before analysis using Fourier transform infrared spectroscopy (FTIR) for organic nitrate quantification. Gas chromatograph-mass spectrometer (GC-MS) data, which was used for product identification (see Sect. S2), was only available for data collected at the reaction endpoints. The FTIR analysis was achieved by integrating the $\sim 1640 \mathrm{~cm}^{-1}$ asymmetric- $\mathrm{NO}_{2}$ stretch unique to organic nitrates (Nielsen et al., 1995). The reaction solutions used were buffered at $10 \mathrm{mM}$ with either a sulfate, acetate, or phosphate buffer system. Hydrolysis reactions were studied at $\mathrm{pH}$ values $0.25,1.0,1.7,2.5,4.0$, and 6.9 .

\subsection{Computational methods}

The thermochemical calculations of a set of reactants, intermediates, and products involved in the proposed reaction pathways of isobutyl nitrate were explored using density functional theory (DFT; Hohenberg and Kohn, 1964; Kohn and Sham, 1965). The set included water $\left(\mathrm{H}_{2} \mathrm{O}\right)$, hydronium ion $\left(\mathrm{H}_{3} \mathrm{O}^{+}\right)$, nitric acid $\left(\mathrm{HNO}_{3}\right)$, isobutyl nitrate $(\mathrm{IBN})$, protonated isobutyl nitrate $\left(\mathrm{IBHN}^{+}\right)$, isobutyl ion $\left(\mathrm{IB}^{+}\right)$, tert-butyl ion $\left(\mathrm{TB}^{+}\right)$, isobutylene (2MP), tert-butyl alcohol (TBA), and isobutyl alcohol (IBA); see Table 1 . The reactions are assumed to run in an acidic environment, such that the hydronium ion is prevalent. First, a systematic, torsional conformational search was performed on the structure of each molecule of the set, excepting water and hydronium ions. This procedure was performed in HyperChem (Hyperchem ${ }^{\mathrm{TM}}$ Professional 7.51, Hypercube, Inc.) with the optimized potentials for liquid simulations (OPLSs) force field (Jorgensen and Tirado-Rives, 1988; Pranata et al., 1991). A maximum of eight simultaneous variations were allowed, with angles changing every step by a maximum range of $180^{\circ}$ at intervals of $15^{\circ}$. Similar structures were filtered, with an acceptance criterion set to $5 \mathrm{kcal} \mathrm{mol}^{-1}$ above the lowest energy conformer. All the following calculations were carried out using the computational chemistry pack-

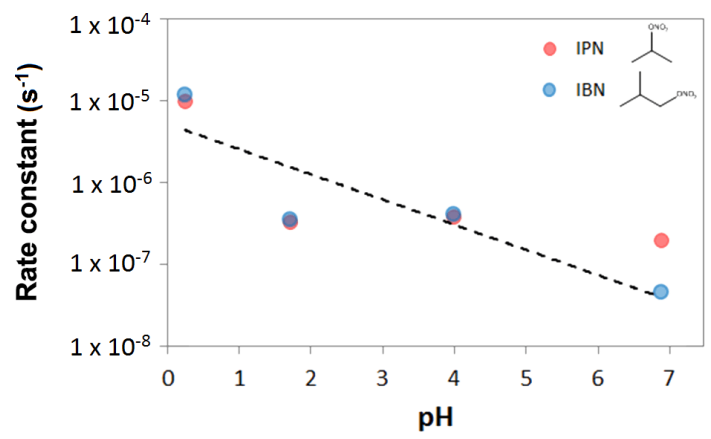

Figure 2. The hydrolysis rate constants $\left(\mathrm{s}^{-1}\right)$ for isopropyl nitrate (IPN; red) and isobutyl nitrate (IBN; blue) as a function of solution $\mathrm{pH}$.

age Q-Chem 4.3 (Shao et al., 2015). Second, the lowest energy conformer was optimized employing the long-range corrected hybrid density functional $\omega \mathrm{B} 97 \mathrm{X}-\mathrm{V}$ (Mardirossian and Head-Gordon, 2014), with the aug-cc-pVTZ basis set (Kendall et al., 1992), and polarizable continuum model (PCM) of implicit aqueous solvent (Truong and Stefanovich, 1995; Barone and Cossie, 1998; Cossi et al., 2003). A highaccuracy grid was employed, as well as extremely tight convergence criteria. Third, frequency calculations were executed on the optimized structures to verify the convergence of the geometry optimizations, and also to determine if the molecule was a stable species or a reaction intermediate. These were run using the same setup described above, plus the inclusion of a thermochemical analysis upon completion of frequency calculations.

\section{Results}

In all experiments, the addition of an organic nitrate standard to aqueous solution resulted in hydrolysis of the organic nitrate functionality, with first order loss rates that increased with solution acidity (Figs. 2, 3). For the tertiary APN, hydrolysis rate constants ranged from $3.2 \times 10^{-5} \mathrm{~s}^{-1}$ at neutral $\mathrm{pH}$ (6.9) to $2.0 \times 10^{-3} \mathrm{~s}^{-1}$ at low $\mathrm{pH}(0.25)$. The hydrolysis rate constants for the secondary isopropyl nitrate and the primary isobutyl nitrate displayed nearly identical kinetics, and had rate constants smaller by more than 2 orders of magnitude relative to the APN, ranging from $1.23 \times 10^{-7} \mathrm{~s}^{-1}$ at neutral $\mathrm{pH}$ (6.9) to $1.1 \times 10^{-5} \mathrm{~s}^{-1}$ at low $\mathrm{pH}(0.25)$, when data from both experiments were averaged together.

The corresponding hydrolysis lifetimes for the organic nitrates studied are shown in Table 2. APN had a condensed phase hydrolysis lifetime of $8.3 \mathrm{~min}$ at low $\mathrm{pH}$, and a lifetime of $8.8 \mathrm{~h}$ at neutral $\mathrm{pH}$. Both of these hydrolysis lifetimes are much shorter than the lifetime of a typical atmospheric aerosol particle. The average hydrolysis lifetimes of isopropyl nitrate and isobutyl nitrate were much larger than 


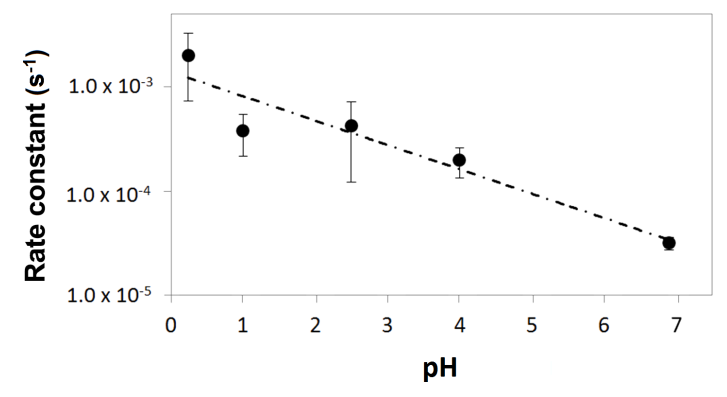

Figure 3. The hydrolysis rate constants $\left(\mathrm{s}^{-1}\right)$ for the $\alpha$-pinenederived nitrate as a function of solution $\mathrm{pH}$. The error bars correspond to 1 standard deviation of replicate measurements.

Table 2. The hydrolysis lifetimes of isopropyl nitrate (IPN), isobutyl nitrate (IBN), and the $\alpha$-pinene-derived nitrate (APN) at varying $\mathrm{pH}$.

\begin{tabular}{llll}
\hline & \multicolumn{3}{c}{ Lifetime } \\
\cline { 2 - 4 } $\mathrm{pH}$ & IPN & IBN & APN \\
\hline 0.25 & $28 \mathrm{~h}$ & $23 \mathrm{~h}$ & $8.3 \mathrm{~min}$ \\
1.0 & - & - & $44 \mathrm{~min}$ \\
1.7 & 35 days & 33 days & - \\
2.5 & - & - & $33 \mathrm{~min}$ \\
4.0 & 30 days & 28 days & $1.3 \mathrm{~h}$ \\
6.9 & $>8$ months & $>8$ months & $8.8 \mathrm{~h}$ \\
\hline
\end{tabular}

those for APN, ranging from approximately 1 day at low $\mathrm{pH}$ to greater than 8 months at neutral conditions.

The $\mathrm{pH}$ dependence of the observed rate constants indicates that the hydrolysis of organic nitrates at low $\mathrm{pH}$ is a specific acid-catalyzed mechanism. In specific acid-catalyzed mechanisms, the transfer of the $\mathrm{H}^{+}$ion from the acid to the reactant is reversible and occurs before the rate determining step, consistent with a unimolecular mechanism. The observed specific acid-catalyzed mechanism is in contrast to Jacobs et al. (2014), who report a general acid-catalyzed mechanism for the hydrolysis of $\beta$-hydroxy organic nitrates. It is important to note, however, that Jacobs et al. (2014) did not observe an increase in hydrolysis rates with increasing buffer concentration, a result that is a defining characteristic of specific acid catalysis.

Previous studies indicate that organic nitrate hydrolysis rates increase with alkyl substitution (Darer et al., 2011; Hu et al., 2011). However, in this study, essentially identical kinetics were observed for the primary isobutyl nitrate and secondary isopropyl nitrate. This similarity can be explained through inspection of the unimolecular hydrolysis mechanism. A proposed reaction mechanism for the acid-catalyzed hydrolysis of IBN is shown in Fig. 4, where rearrangement to a relatively stable tert-butyl carbocation drives the rate of the reaction. A similar observation concerning the relatively large hydrolysis rate constant of a primary organic ni-

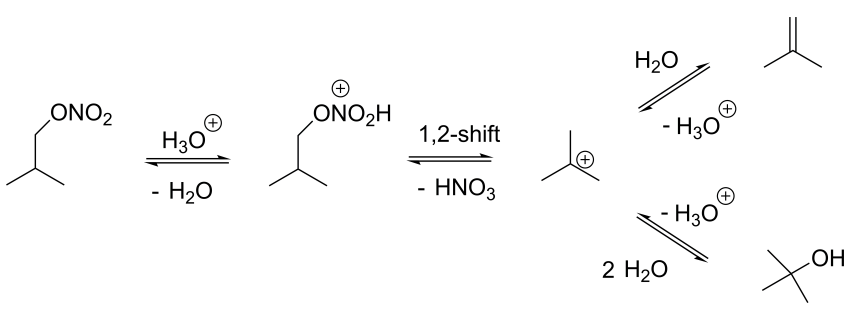

Figure 4. The proposed unimolecular mechanism for isobutyl nitrate (IBN) demonstrating the specific acid catalysis and 1,2-hydride shift rearrangement.

trate was recently reported by Jacobs et al. (2014), who concluded that the resonance stabilization of a primary carbocation increased the rate of a nucleophilic substitution reaction. Since carbocation stability drives the rate of the unimolecular hydrolysis reaction, and rearrangements were not possible for the structures studied in Darer et al. (2011) and Hu et al. (2011), the observed hydrolysis rates in the previous studies followed a trend based on the degree of alkyl substitution, as opposed to this work and Jacobs et al. (2014).

The hydrolysis lifetimes measured for the APN are similar to those previously reported for tertiary hydroxyl nitrates. While not as short as the $0.019 \mathrm{~h}$ reported by Hu et al. (2011), the measured hydrolysis lifetimes of the APN are consistent with the data presented in Fig. 3 of Darer et al. (2011), which we estimate to display a lifetime of approximately $1 \mathrm{~h}$ at $\mathrm{pH}=0.8$. However, a true comparison of the measured hydrolysis rates is not possible, as solution $\mathrm{pH}$ values were not reported in either Darer et al. (2011) or Hu et al. (2011). Nonetheless, one possible explanation for the shorter lifetimes observed in previous work compared to this study may be related to the highly acidic hydrolysis conditions used in previous experiments, which employed the use of strong acids (i.e., acids with negative $\mathrm{pK}_{\mathrm{a}}$ values) ranging up to $2 \mathrm{M}$ (Darer et al., 2011; Hu et al., 2011). If the organic nitrates studied in both Darer et al. (2011) and Hu et al. (2011) also proceeded via specific acid catalysis, a very low $\mathrm{pH}$ environment would likely have led to larger hydrolysis rates than those observed in this study.

To further support the unimolecular reaction mechanism of organic nitrate hydrolysis, theoretical enthalpy and free energy profiles of the proposed isobutyl nitrate reaction mechanism are presented in Fig. 5a and b, respectively. Based on extensive benchmarks, thermochemical calculations in the gas phase at the $\omega \mathrm{B} 97 \mathrm{X}-\mathrm{V} / \mathrm{aug}-\mathrm{cc}-\mathrm{pVTZ}$ level of theory are accurate up to $\sim 3.6 \mathrm{kcal} \mathrm{mol}^{-1}$ (Mardirossian and Head-Gordon, 2014). According to recent literature, the $\omega$ B97X-V/aug-cc-pVTZ level of theory offers an excellent balance between computational cost and accuracy (Chan and Radom, 2011, 2012). Therefore, the main source of potential inaccuracies in our calculations is the use of a PCM implicit solvent, which is known to provide a less rigorous description of charged species (Takano and Houk, 2005). However, 

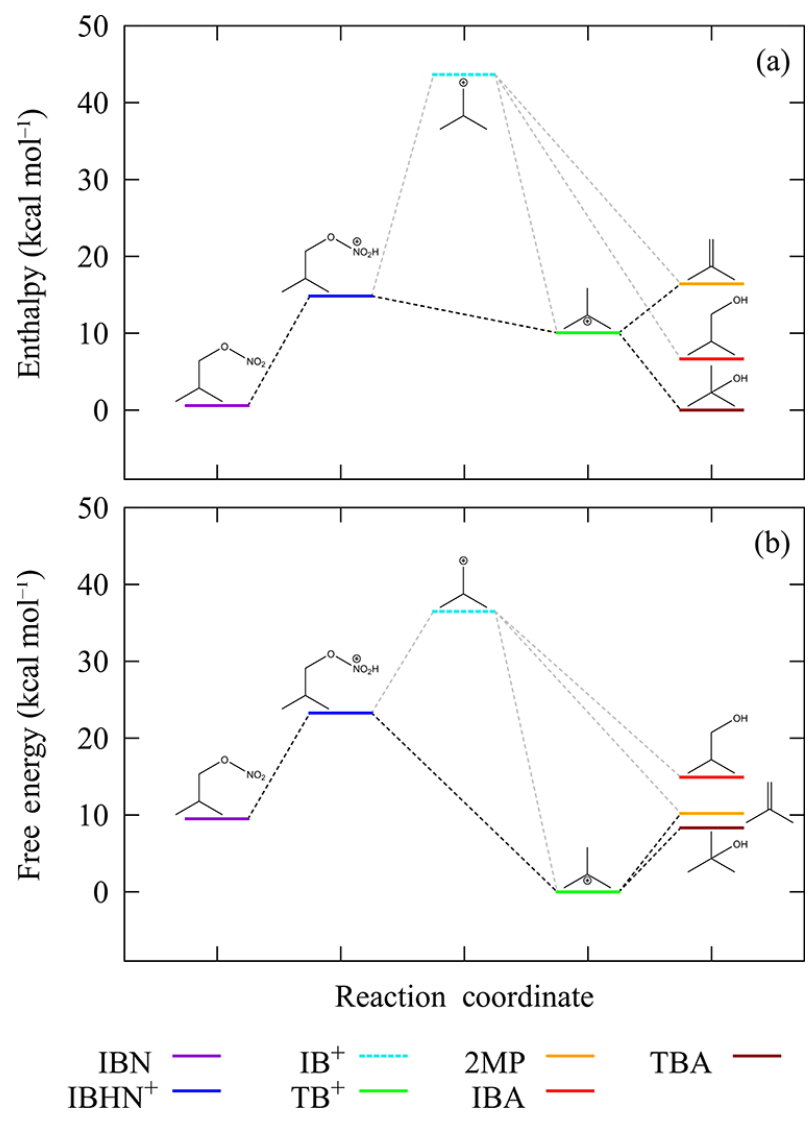

Figure 5. The calculated relative free energies of the intermediates and products of the proposed acid-catalyzed isobutyl nitrate hydrolysis mechanism. See Table 1 for calculation stoichiometry. The reaction is not likely to proceed through the $\mathrm{IB}^{+}$intermediate due to the instability of the carbocation.

the uncertainty due to using PCM is not quantifiable without calculations involving an explicit solvent model, the pursuit of which is beyond the scope of the present study.

According to the DFT calculations, the isobutyl ion $\left(\mathrm{IB}^{+}\right)$ corresponds to a saddle point of the energy profile, thus, it is considered a metastable reaction intermediate rather than a stable species. Due to the instability of the primary isobutyl carbocation $\left(\mathrm{IB}^{+}\right)$, it is likely that a 1,2-hydride shift occurs in concert with bond cleavage of the nitrate group to create the tertiary carbocation intermediate $\left(\mathrm{TB}^{+}\right)$. In addition, geometry optimizations and frequency calculations indicated that protonation of isobutyl nitrate (IBN) occurs on the terminal oxygen of the nitrate rather than the oxygen of the nitrate ester, as shown in Fig. 4, because the latter produces a metastable species.

Comparing the enthalpy and free energy results, it is observed that both the zero-point vibrational energy and entropic contributions play important roles in determining the most probable products.

Without those contributions, a barrier to reach the isobutyl ion is significantly higher and the overall reaction would

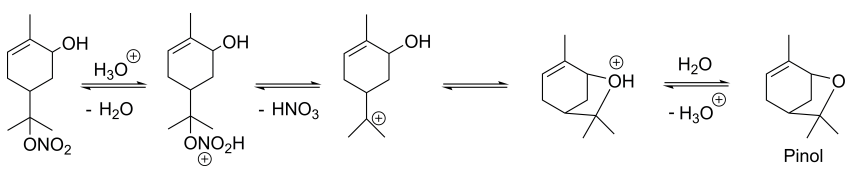

Figure 6. The proposed acid-catalyzed hydrolysis mechanism of an $\alpha$-pinene-derived nitrate.

be much slower. The entropic contribution also impacts the probability of producing isobutylene via an elimination mechanism, among other products. In any case, computations suggest that the energetically favored product is the nucleophilic substitution product, tert-butyl alcohol (TBA). The difference in calculated free energy of the $\mathrm{TB}^{+}$intermediate and the final products is likely within the uncertainty of using an implicit solvation model for charged species.

The much larger observed hydrolysis rate constants for APN, as well as that for a secondary $\beta$-hydroxynitrate from the Jacobs et al. (2014) study, compared to the IPN/IBN systems is related to carbocation stability in the unimolecular mechanism. Due to its relative size, the $\alpha$-pinene-derived carbocation will have greater charge stabilization. Further reaction of the tertiary carbocation intermediate readily occurs, as indicated from the identified product pinol using GC-MS (see Fig. 6), further confirming the unimolecular nature of the organic nitrate hydrolysis under acidic conditions. While theoretical calculations were not conducted for this system, the experimental data and supporting theoretical calculations of IBN hydrolysis indicate that the unimolecular mechanism is favored for organic nitrates in acidic environments. Once the $\alpha$-pinene-derived tertiary carbocation is formed, the reaction can either proceed via unimolecular substitution $\left(S_{N} 1\right)$ or an elimination $(E 1)$ mechanism (Fig. 6; Bleier and Elrod, 2013). In this study, the reaction proceeded via an $S_{N} 1$ pathway to form pinol by intramolecular attack from the secondary hydroxyl group to create a protonated pinol compound. The abstraction of the proton by water completed the acid-catalyzed reaction to create the final pinol product and $\mathrm{H}_{3} \mathrm{O}^{+}$.

Pinol has also been observed as a product of $\alpha$-pinene oxide hydrolysis (Bleier and Elrod, 2013), which is expected to proceed via the same tertiary carbocation intermediate as the APN hydrolysis. In contrast to this study, Bleier and Elrod (2013) also observed the formation of sobrerol and carveol, the alternative $S_{N} 1$ and $E 1$ products, respectively, derived from the tertiary carbocation. While it is peculiar that neither sobrerol nor carveol were detected in this study, the differentiation can at least partially be explained by the greater thermodynamic stability of pinol in comparison to both sobrerol and carveol (Bleier and Elrod, 2013). 


\section{Discussion}

As discussed above, particle phase and cloud water hydrolysis is an important reaction concerning the atmospheric fate of organic nitrates. The conversion of the $\mathrm{RONO}_{2}$ functional group within the aerosol phase to the nitrate ion, which has negligible vapor pressure and will exist within particles depending on $\mathrm{pH}$, will reduce the potential of further reactions re-releasing gas phase $\mathrm{NO}_{x}$ to the atmosphere, such as through organic nitrate photolysis and/or oxidation.

The reported hydrolysis lifetimes for atmospherically relevant hydroxyl nitrates are generally shorter than those reported for oxidation reactions, which range from $2.5-28 \mathrm{~h}$ for gas phase $\mathrm{OH}$ radical oxidation and from $0.7-28 \mathrm{~h}$ for gas phase $\mathrm{O}_{3}$ oxidation (Lee et al., 2014). Gas phase photolysis lifetimes have been reported from $0.50-1.0 \mathrm{~h}$ for carbonyl nitrates (Müller et al., 2014; Xiong et al., 2016) to $\sim 107 \mathrm{~h}$ for monofunctional organic nitrates (Higgins et al., 2014). In comparison, previously reported tertiary organic nitrate hydrolysis lifetimes have been measured as short as $0.019 \mathrm{~h}(\mathrm{Hu}$ et al., 2011) and as short as $0.14 \mathrm{~h}$ under acidic conditions in this study. This indicates that the partitioning of organic nitrates to the particle phase is likely a significant sink for atmospheric $\mathrm{NO}_{x}$ that may critically diminish the potential for long-range transport of $\mathrm{NO}_{x} / \mathrm{O}_{3}$ in the form of organic nitrates. It is important to note that organic nitrates formed from other oxidation processes, such as nitrate radical addition, may produce a larger degree of primary and secondary species that may be more resistant to hydrolysis than the tertiary organic nitrates formed during photooxidation of substituted alkenes (Nah et al., 2016).

To our knowledge, there are currently no reported photolysis or oxidation rate constant measurements for $\alpha$-pinenederived organic nitrates. However, using the EPI Suite available at the Environmental Protection Agency website (http://www.epa.gov/opptintr/exposure/pubs/episuite.htm), gas phase atmospheric lifetimes of APN were calculated to be 1.3 and $0.64 \mathrm{~h}$ for $\mathrm{OH}$ radical and $\mathrm{O}_{3}$-induced oxidation, respectively. Due to the lack of carbonyl functionality, it is expected that the APN photolysis rate is negligibly small. With recently reported aerosol $\mathrm{pH}$ value estimates ranging from $\mathrm{pH} 0.5$ to 3.0 in the southeastern United States (Guo et al., 2015), the corresponding ambient hydrolysis lifetimes of the APN would be on the order of a half hour, which would indicate that particle phase hydrolysis is the principal atmospheric sink for $\alpha$-pinene-derived organic nitrate compounds, in comparison to removal via photolysis and oxidation pathways. Hydrolysis in chamber experiments may be even faster as aerosol $\mathrm{pH}$ has recently been directly measured as low as $\mathrm{pH}-0.68$ for laboratory-generated particles (Rindelaub et al., 2016).

Due to the likely large degree of aerosol phase hydrolysis, current ambient measurements of particle phase organic nitrate concentrations may be underestimating the atmospheric production of organic nitrates. Indeed, this chemistry can represent a dominant fate of $\mathrm{NO}_{x}$ in forested boundary layers and, at low aerosol $\mathrm{pH}$, protonation of the resultant $\mathrm{NO}_{3}^{-}$can represent a dominant source of atmospheric $\mathrm{HNO}_{3}$ (Romer et al., 2016).

The formation of a relatively high vapor pressure product, pinol, from $\alpha$-pinene-derived nitrate hydrolysis may lead to a reduction in aerosol mass by the partitioning of products back into the gas phase, lowering particle mass concentrations. For instance, the calculated vapor pressure of pinol is estimated to be 3 orders of magnitude greater than the original organic nitrate, based on calculations using the EPI Suite (see above). It is important to note that APN hydrolysis products can have olefinic functionality, such as the case with pinol, and may react further in the particle phase, especially under acidic conditions where sulfonation and/or oligomerization can occur. Photo-induced chemistry occurring to aerosol phase products may result in oxidation at the double bond (Bateman et al., 2011). Pinol has also been identified as a hydrolysis product of another $\alpha$-pinene oxidation product, $\alpha$-pinene oxide (Bleier and Elrod, 2013), thus, pinol may be an important tracer for the hydrolysis of $\alpha$-pinenederived species. Both the gas and particle phase fate of pinol warrant further study.

The identification of organic nitrate hydrolysis products is important not only to our understanding of the atmosphere but also to our chemical understanding of the organic nitrate hydrolysis mechanism. Research regarding $\mathrm{RONO}_{2}$ hydrolysis under acidic conditions has been limited and suggests that nucleophilic substitution is the dominant reaction pathway. This study shows that through the unimolecular mechanism, elimination and intramolecular rearrangement/attack are also likely reactive pathways that should be considered when identifying aerosol phase chemical processes and potential tracers of atmospherically relevant compounds.

\section{Conclusions}

A specific acid-catalyzed hydrolysis mechanism was determined for a tertiary $\alpha$-pinene-derived organic nitrate, which has implications for atmospheric air quality and climate. This finding, along with supporting theoretical calculations of the isobutyl nitrate hydrolysis mechanism, helps broaden our chemical understanding of the hydrolysis mechanism of organic nitrates. The hydrolysis rates observed for the organic nitrates studied increased with solution acidity, and the large rates observed for the $\alpha$-pinene-derived organic nitrate further emphasizes the likelihood of particle phase hydrolysis being a sink for organic nitrates and, transitively, atmospheric $\mathrm{NO}_{x}$. It also highlights the importance of ambient aerosol $\mathrm{pH}$ measurements. The hydrolysis of organic nitrates within the particle phase will lead to a decreased effective lifetime for $\mathrm{NO}_{x}$ and, thus, decreased ozone transport. However, the observed organic hydrolysis product, pinol, is relatively volatile and may partition back to the gas phase, decreasing organic 
aerosol mass. In addition to the investigation of $\alpha$-pinenederived organic nitrate photolysis and oxidation, future work is needed to assess how the loss of particle phase organic nitrates impacts aerosol hygroscopicity.

\section{The Supplement related to this article is available online at doi:10.5194/acp-16-15425-2016-supplement.}

Acknowledgements. This research was supported in part through computational resources provided by Information Technology at Purdue University. Paul B. Shepson and Lyudmila V. Slipchenko acknowledge support from the National Science Foundation (grants AGS-1228496 and CHE-1465154, respectively).

Edited by: M. Ammann

Reviewed by: two anonymous referees

\section{References}

Baker, J. W. and Easty, D. M.: Hydrolysis of organic nitrates, Nature, 166, p. 156, doi:10.1038/166156a0, 1950.

Barone, V. and Cossie, M.: Quantum Calculation of Molecular Energies and Energy Gradients in Solution by a Conductor Solvent Model, J. Phys. Chem. A, 102, 1995-2001, 1998.

Bateman, A. P., Nizkorodov, S. A., Laskin, J., and Laskin, A.: Photolytic processing of secondary organic aerosols dissolved in cloud droplets, Phys. Chem. Chem. Phys., 13, 12199-12212, 2011.

Bean, J. K. and Hildebrandt Ruiz, L.: Gas-particle partitioning and hydrolysis of organic nitrates formed from the oxidation of apinene in environmental chamber experiments, Atmos. Chem. Phys., 16, 2175-2184, doi:10.5194/acp-16-2175-2016, 2016.

Bleier, D. B. and Elrod, M. J.: Kinetics and Thermodynamics of Atmospherically Relevant Aqueous Phase Reactions of $\alpha$-Pinene Oxide, J. Phys. Chem. A, 117, 4223-4232, 2013.

Boschan, R., Merrow, R. T., and van Dolah, R.: The chemistry of nitrate esters, Chem. Rev., 55, 485-510, 1955.

Boyd, C. M., Sanchez, J., Xu, L., Eugene, A. J., Nah, T., Tuet, W. Y., Guzman, M. I., and Ng, N. L.: Secondary organic aerosol formation from the $\beta$-pinene $+\mathrm{NO}_{3}$ system: effect of humidity and peroxy radical fate, Atmos. Chem. Phys., 15, 7497-7522, doi:10.5194/acp-15-7497-2015, 2015.

Chan, B. and Radom, L.: Assessment of theoretical procedures for hydrogen-atom abstraction by chlorine, and related reactions, Theor. Chem. Acc., 130, 251-260, 2011.

Chan, B. and Radom, L.: Approaches for Obtaining Accurate Rate Constants for Hydrogen Abstraction by a Chlorine Atom, J. Phys. Chem. A, 116, 3745-3752, 2012.

Cossi, M., Rega, N., Scalmani, G., and Barone, V.: Energies, structures, and electronic properties of molecules in solution with the C-PCM solvation model, J. Comput. Chem., 24, 669-681, 2003.

Darer, A. I., Cole-Filipiak, N. C., O'Connor, A. E., and Elrod, M. J.: Thermodynamics and kinetics of the hydrolysis of atmospherically relevant organonitrates and organosulfates, Environ. Sci. Technol., 45, 1895-1902, 2011.
EPA: Second External Review Draft of the Integrated Science Assessment of Ozone and related Photochemical Oxidants, Research Triangle Park, N.C., Environmental Protection Agency, Report no. EPA/600/R-10/076B, 2011

Fiscus, E. D., Booker, F. L., and Burkey, K. O.: Crop responses to ozone: uptake, modes of action, carbon assimilation and partitioning, Plant Cell Environ., 28, 997-1011, 2005.

Guenther, A., Hewitt, C. N., Erickson, D., Fall, R., Geron, C., Graedel, T., Harley, P., Klinger, L., Lerdau, M., Mckay, W. A., Pierce, T., Scholes, B., Steinbrecher, B. R., Tallamraju, R., Taylor, J., and Zimmerman, P.: A global model of natural volatile organic compound emissions, J. Geophys. Res., 100, 8873-8892, 1995.

Guenther, A. B., Jiang, X., Heald, C. L., Sakulyanontvittaya, T., Duhl, T., Emmons, L. K., and Wang, X.: The Model of Emissions of Gases and Aerosols from Nature version 2.1 (MEGAN2.1): an extended and updated framework for modeling biogenic emissions, Geosci. Model Dev., 5, 1471-1492, doi:10.5194/gmd-51471-2012, 2012.

Guo, H., Xu, L., Bougiatioti, A., Cerully, K. M., Capps, S. L., Hite Jr., J. R., Carlton, A. G., Lee, S.-H., Bergin, M. H., Ng, N. L., Nenes, A., and Weber, R. J.: Fine-particle water and $\mathrm{pH}$ in the southeastern United States, Atmos. Chem. Phys., 15, 5211-5228, doi:10.5194/acp-15-5211-2015, 2015.

Higgins, C. M., Evans, L. A., Lloyd-Jones, G. C., Shallcross, D. E., Tew, D. P., and Orr-Ewing, A. J.: Quantum Yields for Photochemical Production of $\mathrm{NO}_{2}$ from Organic Nitrates at Tropospherically Relevant Wavelengths, J. Phys. Chem. A, 118, 27562764, 2014.

Hohenberg, P. and Kohn, W.: Inhomogeneous electron gas, Phys. Rev., 136, B864-B871, 1964.

Hu, K. S., Darer, A. I., and Elrod, M. J.: Thermodynamics and kinetics of the hydrolysis of atmospherically relevant organonitrates and organosulfates, Atmos. Chem. Phys., 11, 8307-8320, doi:10.5194/acp-11-8307-2011, 2011.

IPCC 2007: The Physical Science Basis. Contribution of Working Group I to the Fourth Assessment Report of the Intergovernmental Panel on Climate Change, edited by: Solomon, S., Qin, D., Manning, M., Chen, Z., Marquis, M., Averyt, K. B., Tignor, M., and Miller, H. L., Cambridge University Press, Cambridge, UK and New York, USA, 2007.

Jacobs, M. I., Burke, W. J., and Elrod, M. J.: Kinetics of the reactions of isoprene-derived hydroxynitrates: gas phase epoxide formation and solution phase hydrolysis, Atmos. Chem. Phys. 14, 8933-8946, doi:10.5194/acp-14-8933-2014, 2014.

Jorgensen, W. L. and Tirado-Rives, J.: The OPLS [optimized potentials for liquid simulations] potential functions for proteins, energy minimizations for crystals of cyclic peptides and crambin, J. Am. Chem. Soc., 110, 1657-1666, 1988.

Kendall, R. A., Dunning, T. H., and Harrison, R. J.: Electron affinities of the first-row atoms revisited. Systematic basis sets and wave functions, J. Chem. Phys., 96, 6796-6806, 1992.

Kohn, W. and Sham, L. J.: Self-Consistent Equations Including Exchange and Correlation Effects, Phys. Rev., 140, A1133-A1138, 1965.

Lee, L., Teng, A. P., Wennberg, P. O., Crounse, J. D., and Cohen, R. C.: On rates and mechanisms of $\mathrm{OH}$ and $\mathrm{O}_{3}$ Reactions with isoprene-derived hydroxyl nitrates, J. Phys. Chem. A, 118, 16221637, 2014. 
Liu, S., Shilling, J. E., Song, C., Hiranuma, N., Zaveri, R. A., and Russell, L. M.: Hydrolysis of Organonitrate Functional Groups in Aerosol Particles, Aerosol Sci. Tech., 46, 1359-1369, 2012.

Mardirossian, N. and Head-Gordon, M.: $\omega$ B97X-V: A 10parameter, range-separated hybrid, generalized gradient approximation density functional with nonlocal correlation, designed by a survival-of-the-fittest strategy, Phys. Chem. Chem. Phys., 16, 9904-9924, 2014.

Müller, J.-F., Peeters, J., and Stavrakou, T.: Fast photolysis of carbonyl nitrates from isoprene, Atmos. Chem. Phys., 14, 24972508, doi:10.5194/acp-14-2497-2014, 2014.

Nah, T., Sanchez, J., Boyd, C. M., and Ng, N. L.: Photochemical Aging of $\alpha$ pinene and $\beta$ pinene Secondary Organic Aerosol formed from Nitrate Radical Oxidation, Environ. Sci. Technol., 50, 222-231, 2016.

Nielsen, T., Egelov, A. H., Granby, K., and Skov, H.: Observations on particulate organic nitrates and unidentified components of $\mathrm{NO}_{y}$, Atmos. Environ., 29, 1757-1769, 1995.

Pinto, R. M. A., Salvador, J. A. R., and Le Roux, C.: Bismuth(III) salts mediated regioselective ring opening of epoxides: an easy route to halohydrins and betahydroxy nitrates, Tetrahedron, 63, 9221-9228, 2007.

Pranata, J., Wierschke, S. G., and Jorgensen, W. L.: OPLS potential functions for nucleotide bases. Relative association constants of hydrogen-bonded base pairs in chloroform, J. Am. Chem. Soc., 113, 2810-2819, 1991.

Raaschou-Nielsen, O., Andersen, Z. J., Beelen, R., Samoli, E., Stafoggia, M., Weinmayr, G., Hoffmann, B., Fischer, P., Nieuwenhuijsen, M. J., Brunekreef, B., Xun, W. W., Katsouyanni, K., Dimakopoulou, K., Sommar, J., Forsberg, B., Modig, L., Oudin, A., Oftedal, B., Schwarze, P. E., Nafstad, P., De Faire, U., Pedersen, N. L. Ostenson, C. G., Fratiglioni, L., Penell, J., Korek, M., Pershagen, G., Eriksen, K. T., Sorensen, M., Tjonneland, A., Ellermann, T., Eeftens, M., Peeters, P. H., Meliefste, K., Wang, M., Bueno-de-Mesquita, B., Key, T. J., de Hoogh, K., Concin, H., Nagel, A., Vilier, S., Grioni, V., Krogh, M. Y., Tsai, F., Ricceri, C., Sacerdote, C., Galassi, E., Migliore, A., Ranzi, G., Cesaroni, G., Badaloni, C., Forastiere, F., Tamayo, I., Amiano, P., Dorronsoro, M., Trichopoulou, A., Bamia, C., Vineis, P., and Hoek, G.: Air pollution and lung cancer incidence in 17 European cohorts: prospective analyses from the European Study of Cohorts for Air Pollution Effects (ESCAPE), Lancet Oncol., 14, 813-822, 2013.

Ramanathan. V., Crutzen, P. J., Kiehl, J. T., and Rosenfeld, D.: Aerosols, Climate, and the Hydrological Cycle, Science, 294, 2119-2124, 2001.

Rindelaub, J. D., McAvey, K. M., and Shepson, P. B.: The photochemical production of organic nitrates from $\alpha$-pinene and loss via acid-dependent particle phase hydrolysis, Atmos. Environ., 100, 193-201, 2015.
Rindelaub, J. D., Craig, R. L., Nandy, L., Bondy, A. L., Dutcher, C. S., Shepson, P. B., and Ault, A. P.: Direct Measurement of $\mathrm{pH}$ in Individual Particles via Raman Microspectroscopy and Variation in Acidity with Relative Humidity, J. Phys. Chem. A, 120, 911 917, 2016

Rollins, A. W., Smith, J. D., Wilson, K. R., and Cohen, R. C. Real Time In Situ Detection of Organic Nitrates in Atmospheric Aerosols, Environ. Sci. Technol., 44, 5540-5545, 2010.

Romer, P. S., Duffey, K. C., Wooldridge, P. J., Allen, H. M., Ayres, B. R., Brown, S. S., Brune, W. H., Crounse, J. D., de Gouw, J., Draper, D. C., Feiner, P. A., Fry, J. L., Goldstein, A. H., Koss, A., Misztal, P. K., Nguyen, T. B., Olson, K., Teng, A. P., Wennberg, P. O., Wild, R. J., Zhang, L., and Cohen, R. C.: The lifetime of nitrogen oxides in an isoprene-dominated forest, Atmos. Chem. Phys., 16, 7623-7637, doi:10.5194/acp-16-7623-2016, 2016.

Scott, C. E., Rap, A., Spracklen, D. V., Forster, P. M., Carslaw, K. S., Mann, G. W., Pringle, K. J., Kivekäs, N., Kulmala, M., Lihavainen, H., and Tunved, P.: The direct and indirect radiative effects of biogenic secondary organic aerosol, Atmos. Chem. Phys., 14, 447-470, doi:10.5194/acp-14-447-2014, 2014.

Shao, Y. H., Gan, Z. T., Epifanovsky, E., Gilbert, A. T. B., Wormit, M., Kussmann, J., Lange, A. W., Behn, A., Deng, J., Feng, X. T., Ghosh, D., Goldey, M., Horn, P. R., Jacobson, L. D., Kaliman, I., Khaliullin, R. Z., Kus, T., Landau, A., Liu, J., Proynov, E. I., Rhee, Y. M., Richard, R. M., Rohrdanz, M. A., Steele, R. P., Sundstrom, E. J., Woodcock, H. L., Zimmerman, P. M., Zuev, D., Albrecht, B., Alguire, E. et al.: Advances in molecular quantum chemistry contained in the Q-Chem 4 program package, Mol. Phys., 113, 184-215, 2015.

Takano, Y. and Houk, K. N.: Benchmarking the Conductor-like Polarizable Continuum Model (CPCM) for Aqueous Solvation Free Energies of Neutral and Ionic Organic Molecules, J. Chem. Theory Comput., 1, 70-77, 2005.

Truong, T. N. and Stefanovich, E. V.: A new method for incorporating solvent effect into the classical, ab initio molecular orbital and density functional theory frameworks for arbitrary shape cavity, Chem. Phys. Lett., 240, 253-260, 1995.

Xiong, F., Borca, C. H., Slipchenko, L. V., and Shepson, P. B.: Photochemical degradation of isoprene-derived 4,1-nitrooxy enal, Atmos. Chem. Phys., 16, 5595-5610, doi:10.5194/acp-16-55952016, 2016.

$\mathrm{Xu}$, L., Suresh, S., Guo, H., Weber, R. J., and Ng, N. L.: Aerosol characterization over the southeastern United States using highresolution aerosol mass spectrometry: spatial and seasonal variation of aerosol composition and sources with a focus on organic nitrates, Atmos. Chem. Phys., 15, 7307-7336, doi:10.5194/acp15-7307-2015, 2015. 